\title{
International Courts and Global Democratic Values: Participation, Accountability, and Justification
}

\author{
Jonathan Kuyper and Theresa Squatrito \\ Forthcoming in Review of International Studies
}

It is widely noted that world politics suffers from a democratic deficit. ${ }^{1}$ In a post-Cold War era characterized by globalization and deep interdependence, this deficit arises from two sources.

First, the actions of national governments increasingly have an effect beyond their own territorial borders creating transnational spillovers. ${ }^{2}$ Second, key agents of global governance international organizations (IOs) and their bureaucracies, non-state actors and private agents exercise pervasive forms of authority. In both instances, individuals and collectives are oftentimes divorced from the decision-making processes that determine their lives. ${ }^{3}$ If the notion of collective self-governance - in which affected parties exercise popular sovereignty - is to make sense in a global age, democracy must go beyond the nation state. ${ }^{4}$ Over the past two decades in particular, the cause and consequence of the global democratic deficit have been recognized, conceptualized, and problematized by international relations (IR) scholars, political theorists, lawyers, and activists.

This article contributes to work on global democracy by looking at the role of international courts (ICs). Although courts are typically understood as essential to national democratization, their presence in transnational governance has not been adequately appreciated by global democrats. This is somewhat ironic because early work on global democracy, especially that by David Held and Daniele Archibugi, suggested that ICs specifically - and the

\footnotetext{
${ }^{1}$ Richard Higgott and Eva Erman, 'Deliberative Global Governance and the Question of Legitimacy: What Can We Learn from the WTO', Review of International Studies, 36:2 (2010), pp. 449-70. See also Klaus Dingwerth, 'Global Democracy and the Democratic Minimum: Why a Procedural Account Alone is Insufficient', European Journal of International Relations, 20:4 (2014), pp. 1124-47.

2 David Held, 'Cosmopolitanism: Globalization Tamed?' Review of International Studies, 29:4 (2003), pp. 465-80.

3 Jan Aart Scholte, 'Reinventing Global Democracy', European Journal of International Relations, 20:1 (2014), pp. 3-28.

${ }^{4}$ Raffaele Marchetti, 'A matter of drawing boundaries: Global democracy and international exclusion', Review of International Studies, 34:2 (2008), pp. 207-224.
} 
legalization of world politics more generally - would be essential for global democracy. ${ }^{5}$ Yet today, there exists twenty-three permanent, operational international judicial bodies that have issued tens of thousands of binding rulings. ${ }^{6}$ Against this background, we examine the relationship(s) between ICs and the ongoing process of global democratization.

The core question of this article is if, how, and in which ways ICs bolster or undermine democratic values beyond the state. We contend that ICs are indeed able to advance global democratic values and shape democratic practices. They can do so by fostering equal participation, accountability, and public justification that link individuals directly with sites of authority beyond their own nation-state. We maintain that the ability of ICs to promote these values is conditioned by institutional design choices concerning access rules, review powers, and provisions regarding judicial reason-giving. We canvass these design features of different ICs and assess the promises and pitfalls for global democratization. Doing so enables us to discuss how design choices condition the practice and behavior of ICs. Although the internal democratic legitimacy of ICs is important, this article is concerned with how ICs promote the democratization of world politics at large. ${ }^{7}$

Methodologically, we draw upon an original dataset covering the 24 ICs in existence during the post-World War II period. This dataset contains data on ICs' formal rules governing access for private, non-state actors, review powers, and judicial reason-giving. The numerical increase in ICs enables us to talk about global democratization over time while our data on design features in all 24 courts across different world regions speaks to democratization across space. The article is thus particularly novel in bridging normative theory with substantive and systematic empirical data. ${ }^{8}$

The article proceeds in four sections. First we discuss the literature on global democracy emphasizing the recent turn toward striving for democratic values under pluralist conditions.

\footnotetext{
${ }^{5}$ Daniele Archibugi and David Held (eds.), Cosmopolitan Democracy: An Agenda for a New World Order (Cambridge: Polity Press, 1995).

${ }^{6}$ Karen J. Alter, The New Terrain of International Law: Courts, Politics, Rights (Princeton: Princeton University Press, 2014), p. 75.

${ }^{7}$ Armin von Bogdandy, 'The Democratic Legitimacy of International Courts: A Conceptual Framework', Theoretical Inquiries in Law, 14:2 (2013), p. 370.

${ }^{8}$ Other scholars have made significant strides in connecting some strands of normative (moral) theorising with international relations literature. See, for instance, Toni Erskine, 'Locating Responsibility: The problem of Moral Agency in International Relations', in Christian Reus-Smit and Duncan Snidal (eds.), Oxford Handbook of International Relations (Oxford: Oxford University Press, 2008), pp. 699-707. This article is the first to look specifically at the nexus of ICs and normative values of global democratization.
} 
Drawing on the current state of the literature, we outline three values that together allow us to examine the advancement or recession of global democratization. Second we underline the prevalence and importance of ICs and suggest that ICs may have a pivotal role to play in global democratization. Third we look at how equal participation, accountability, and justification are secured by different ICs and note which institutional design features are critical for each value. We discuss both the promise and pitfalls of realizing these values by looking at how these values are realized or inhibited in practice. The conclusion discusses future directions of research by linking global democratization with debates about the legitimation of global governance at large.

\section{Global Democratization}

Work in the field of international normative political theory has flourished in recent years. ${ }^{9}$ Roughly speaking, three separate strands can be discerned. First, global justice scholars have examined the appropriate allocation of burdens and benefits to be distributed across national borders and scrutinized how various institutional (pre)conditions trigger different moral duties. ${ }^{10}$ Second, theorists and philosophers working in the just war tradition have examined the historical and ethical rules governing inter-state warfare and conflict. ${ }^{11}$ Finally, global democrats have probed how the legitimacy of world politics relates to the notion of collective self-governance which stands at the heart of democratic governance within national polities. ${ }^{12}$

This article is concerned with global democratization. The notion of a democratic deficit - in which decisions taken beyond the state pierce national sovereignty and expose individuals to rules they have not helped formulate - is now extensively recognized. ${ }^{13}$ The global democratic deficit, tethered as it is to globalization, increased national interdependence, and the prominence

\footnotetext{
${ }^{9}$ For a recent and comprehensive overview, see Anthony F. Lang, International Political Theory: An Introduction (New York: Palgrave Macmillan, 2015).

${ }^{10}$ Andrea Sangiovanni, 'Justice and Priority of Politics to Morality', Journal of Political Philosophy 15:2 (2008), pp. 137-164. See also Laura Valentini and Tiziana Torresi, 'Introduction - International law and global justice: a happy marriage', Review of International Studies, 37:5 (2011), pp. 2035-2041.

${ }^{11}$ Michael Walzer, Just and Unjust Wars: A Moral Argument With Historical Illustrations (4th edn, New York: Basic Books, 2006). See also Seth Lazar, 'Necessity and non-combatant immunity', Review of International Studies, 40:1 (2014), pp. 53-76.

${ }^{12}$ Adrian Little and Kate Macdonald, 'Pathways to Global Democracy: Escaping the Statist Imaginary', Review of International Studies, 39:4 (2013), pp. 789-813.

${ }^{13}$ Held, 'Cosmopolitanism: Globalization Tamed?; Dingwerth, 'Global Democracy and the Democratic Minimum'. See also Johan Karlsson Schaffer, 'The boundaries of transnational democracy: alternatives to the all-affected principle', Review of International Studies, 38:2 (2012), pp. 321-42.
} 
of international law, has forced attention toward the normative legitimacy and sources of authority that underpin transnational social, economic, and political decision-making. While it is possible to assess the sociological legitimacy of global authority, ${ }^{14}$ it is also clear that authoritative relationships can be legitimated through democratic practice in which the 'governed' or 'affected' parties participate in the formation of those authoritative rules which bind them. ${ }^{15}$

In order to dampen the global democratic deficit, numerous proposals, models, blueprints, and schemes have been touted to give individuals more direct say in how their lives are governed. Although a full exposition is neither possible nor necessary here, early work was often formulated in terms of idealized 'models' or 'terminal blueprints' that could be strived toward. ${ }^{16}$ For instance, the model of cosmopolitan democracy came with a variety of short- and long-term institutional prescriptions including international courts, transnational parliaments, and multi-level governance architecture which would enable individuals to participate in global decision-making. ${ }^{17}$ World government scholars went beyond the cosmopolitan model and outlined a hierarchical and encompassing system of state-like institutions that could be replicated at the global level. This would include a world parliament, global constitution, and federal government with coercive power. ${ }^{18}$ In a different vein, global civil society advocates have often promoted a deliberative model that puts democratizing faith in non-state actors who can employ different discourses to oppose, contest, and shape more formal international politics. ${ }^{19}$ Intergovernmental models, radical proposals, pragmatist suggestions, and postmodern models are

\footnotetext{
${ }^{14}$ Lisa Dellmuth and Jonas Tallberg, 'The social legitimacy of international organisations: Interest representation, institutional performance, and confidence extrapolation in the United Nations', Review of International Studies, 41:3 (2015), pp. 451-475.

${ }^{15}$ Marchetti, 'A matter of drawing boundaries'.

${ }^{16}$ For an overview, see Daniel Bray and Steven Slaughter, Global Democratic Theory: Problems and Possibilities (Cambridge: Polity Press, 2015).

${ }^{17}$ David Held, Democracy and the Global Order: From the Modern State to Cosmopolitan Governance (Cambridge: Polity Press, 1995).

${ }^{18}$ Raffaele Marchetti, Global Democracy: For and Against - Ethical Theory, Institutional Design, and Social Struggles (Abingdon: Routledge, 2008). William E. Scheuerman, 'Cosmopolitanism and the world state', Review of International Studies, 40:3 (2014), pp. 419-441.

${ }^{19}$ John S. Dryzek, Deliberative Democracy and Beyond: Liberals, Critics, Contestation (Oxford: Oxford University Press, 2000). See also James Bohman, 'Democratising the Global Order: From Communicative Freedom to Communicative Power', Review of International Studies, 36:2 (2010), pp. 431-47; Peter Newell, 'Democratising biotechnology? Deliberation, participation and social regulation in a neo-liberal world', Review of International Studies, 36:2 (2010), pp. 471-491.
} 
just several of the other prescriptions for giving individuals a greater say in the transnational forces which afflict their lives. ${ }^{20}$

However, the literature on global democracy has shifted away from this strategy of proposing idealized models to be realized as closely as possible. ${ }^{21}$ Instead, scholars and practitioners are now searching for how different democratic values and practices emerge under existing conditions and devising ways to advance their attainment. This method, broadly speaking, mirrors a turn in global justice debates toward non-ideal and (so-called) realist theory. ${ }^{22}$ Instead of stipulating a fully-democratic institutional scheme that serves as a target or benchmark, we should work from within current arrangements to make productive steps forward seeking to understand which values and principles should regulate different institutional arrangements for global democratization. ${ }^{23}$

This article joins this general reorientation of the literature. The question then becomes: which democratic values should be sought in world politics generally, and through ICs specifically? We seek to establish if, how, and under which conditions ICs enable practices of equal participation, accountability, and public justification beyond the state. We have two methodological rationales for selecting these values. First, these values reflect three prominent strands of democratic thinking: participatory, liberal, and deliberative. Participatory democrats stress the importance of individual involvement in forming rules and laws. Liberal democrats highlight the centrality of holding decision-makers to account and the role of a balance-of-power

\footnotetext{
${ }^{20}$ See respectively: Robert Keohane, Steven Macedo and Andrew Moravcsik, 'Democracy-Enhancing multilateralism', International Organization, 63:1 (2009), pp. 1-31; Theresa Squatrito, 'Conditions of Democracyenhancing Multilateralism: Expansion of Rights Protections in Europe?', Review of International Studies, 38:4 (2012), pp. 707-733; Antonio Negri and Michael Hardt, Empire (Harvard: Harvard University Press, 2000); Daniel Bray, 'Pragmatic Ethics and the Will to Believe in Cosmopolitanism', International Theory, 5:3 (2011), pp. 446476; Shaffer, 'The boundaries of transnational democracy'.

${ }^{21}$ Little and Macdonald, 'Pathways to Global Democracy'; Mathias Koenig-Archibugi, 'Is global democracy possible?' European Journal of International Relations, 17:3 (2010), pp. 519-542.

${ }^{22}$ See Laura Valentini, 'Ideal vs. Non-ideal Theory: A Conceptual Map', Philosophy Compass, 7:9 (2012), pp.654664. There are also interesting connections with 'practice-dependent' thought in justice debates. Practice-dependent arguments maintain that the "scope, content, and justifications of justice depends on the structure and form of practices that the conception is intended to cover". See Sangiovanni, 'Justice and Priority of Politics to Morality', $p$. 138. Transposing this argument to global democracy would entail that the appropriate normative values and institutional designs necessary depend on the shape, form, and authority of global governance itself. While we find connections with practice-dependence and non-ideal theory in global justice intriguing, exploring those connections lies outside the scope of this article.

${ }^{23}$ We use the term 'global democracy' to refer to proposals or blueprints, and 'global democratization' to signify the ongoing attainment of democratic values.
} 
in that relationship. Finally deliberative scholars iterate the formation of preferences through public reasoning that stands at the core of democratization efforts.

Second, these values represent a synthesis of recent work on global democratization from IR, political theory, and international law. Magdelena Bexell, Jonas Tallberg, and Anders Uhlin put forward participation and accountability as the core values civil society actors can promote in global democratic governance. ${ }^{24}$ These authors also advocate the importance of deliberative conceptions of global democratization. Similarly, Klaus Dingwerth, in a recent article, stresses "the benefits of disaggregating the concept of (global) democratic governance" into inclusiveness, transparency, accountability, and deliberation. ${ }^{25}$ In political theory, Kate Macdonald and Terry Macdonald highlight public disempowerment, accountability, and transparency as the relevant criteria for global democratization. ${ }^{26}$ Public disempowerment requires giving affected parties the ability to signal (dis)approval and sanction authoritative rulemakers, and transparency provides public justification for how authority is wielded. ${ }^{27}$ Within international law - especially the field of global administrative law - Nico Krisch advocates the importance of accountability and contestation (participation and deliberation) for democratizing the postnational order. ${ }^{28}$

\section{Values of Democratization}

From this brief inter-disciplinary review of global democratic scholarship, convergence can be noted. There is rough agreement on both the ways to pursue global democratization - as a set of values derived from democratic theory - and on what those values might be. We identify equal participation, accountability, and public justification as central. While there are certainly other candidates, less consensus exists on these values. For instance, some might question why we

\footnotetext{
${ }^{24}$ Magdelena Bexell, Jonas Tallberg, and Anders Uhlin, 'Democracy in global governance: The promise and pitfalls of transnational actors', Global Governance, 16:1 (2010), pp. 85-6.

${ }^{25}$ Dingwerth, 'Global Democracy and the Democratic Minimum', p. 1141. We are aware that Dingwerth also highlights the importance of moving beyond purely procedural assessments of global democratization. As we discuss, there are substantive limitations to the attainment of each value that we draw out. As such, we concur with Dingwerth's general position but continue to emphasize the importance of striving for normative values.

${ }^{26}$ Terry Macdonald and Kate Macdonald, 'Non-Electoral Accountability in Global Politics: Strengthening Democratic Control within the Global Garment Industry', European Journal of International Law, 17:1 (2006), pp. 89-119.

${ }^{27}$ Ibid., p. 104.

${ }^{28}$ Nico Krisch, Beyond Constitutionalism: The Pluralist Structure of Postnational Law (Oxford: Oxford University Press, 2010), 78-88.
} 
have not included human rights in our list of relevant democratic values. While we think that protecting human rights is an important function for ICs to consider, the values of accountability and public justification go a long way toward safeguarding individual rights. Moreover, there are significant debates in political theory about whether human rights are a necessary condition for democracy - a debate without consensus. ${ }^{29}$ As such, we have not made 'human rights' a separate democratic value, but nor do we preclude its importance or potential as a value for future research.

The goal of this article thus remains to determine if ICs can embody these values, through which modes and mechanisms this can occur, and whether this provides a springboard for global democratization. From our analysis, it becomes clear that ICs can be designed to engender these values to greater or lesser degrees, variation which is conditioned by institutional design features. There are also substantive limitations (beyond issues of institutional design) that inhibit the realization of different values in practice, such as unequal distribution of resources, geographical remoteness, and epistemic hindrances. ${ }^{30}$ As such, we are interested in both the internal design features of ICs that enable or hamper these democratic values, as well as the effect on the wider system of world politics. Indeed, it is the ways in which ICs enable affected individuals to be connected democratically with other sites of authoritative rule-making beyond the state that is key to their democratizing potential. Before moving on to this analysis, we flesh out each value in more substantive terms.

Equal participation means that citizens affected by the authoritative exercise of public power should have the opportunity and ability to be involved in how that authority is wielded. This entails equal capacity to set the agenda as well as shape the rules, laws, and regulations that will affect their lives. We recognize that equality of participation may often rest upon forms of representation as individuals cannot always be directly involved in all decision-making processes. National representatives or other self-appointed representatives (interest groups, nongovernmental organizations, etc.) can all help connect individuals with sites of public power. ${ }^{31}$ Precisely how equal participation is secured will and should vary depending upon the institutional scheme in need of democratic regulation.

\footnotetext{
${ }^{29}$ On this debate, see Seyla Benhabib, 'Claiming rights across borders: International human rights and democratic sovereignty’, American Political Science Review 103:4 (2009), pp. 691-704.

${ }^{30}$ These, as well as other limitations, are fleshed out in the third section examining the institutional design features related to each value.

${ }^{31}$ Macdonald and Macdonald, 'Non-Electoral Accountability'.
} 
Accountability, in a democratic sense, means that those affected by decision-making should have the right to hold power wielders "to a set of standards, to judge whether they have fulfilled their responsibilities in light of these standards, and to impose sanctions if they determine that these responsibilities have not been met". ${ }^{32}$ This criterion gives affected individuals the opportunity to hold decision-makers at different levels of governance accountable for their actions and stop the arbitrary exercise of power which can undercut individual autonomy. Operative accountability mechanisms provide an ex ante incentive for decisionmakers to take consideration of how affected parties will react to decisions being made in their name.

Finally, public justification provides those affected by decisions with a rationale for how rules are being formulated and applied in various contexts. ${ }^{33}$ This value derives largely from work in the field of deliberative democracy that stresses the importance of providing reciprocal and generalizable arguments for how public power is exercised and how it is connected to the public use of reasoning. ${ }^{34}$ Reciprocity means that justification is mutually-acceptable to parties in a deliberation, whereas generalizability connotes a set of reasons that could be shared by affected parties due to shared institutional or moral structures. Public justification thus rests upon the offering of reasoned argument and, in turn, the acceptance of those reasons by affected individuals.

These values provide the basis for our analysis of how democratic practice may be instantiated and deepened beyond the nation-state. The criteria do not presuppose any specific institutional structure, indeed quite the opposite: it recognizes that the specific way different values are constructed depends on the type of institutional scheme being regulated and the diverse means available to individuals seeking democratic control over authority. ${ }^{35}$ It is worth noting that the methodological move toward 'values of democratization' has been criticized on

\footnotetext{
${ }^{32}$ Ruth W. Grant and Robert Keohane, 'Accountability and Abuses of Power in World Politics', American Political Science Review, 99:1 (2005), p. 29. See also Jonathan W. Kuyper, 'Global Democratization and International Regime Complexity', European Journal of International Relations, 20:3 (2014), pp. 620-46.

${ }^{33}$ Rainer Forst, The Right to Justification: Elements of a Constructivist Theory of Justice. (New York: Columbia University Press, 2011). See also Peter Newell, 'Democratising biotechnology? Deliberation, participation and social regulation in a neo-liberal world', Review of International Studies, 36:2 (2010), pp. 471-491.

${ }^{34}$ Jürgen Habermas, Between Facts and Norms (Cambridge, MA: MIT Press, 1996); Dryzek, Deliberative Democracy.

${ }^{35}$ Little and Macdonald, 'Pathways to Global Democracy'.
} 
the grounds that democracy cannot be conceptually disaggregated so simply. ${ }^{36}$ While we recognize this issue, we maintain that looking at these values helps make clear the trade-offs and conflicts between values as well as the way values can be mutually-supportive. In our analysis, therefore, we identify the institutional design features of ICs that are crucial to these democratic values as well as potential pitfalls for global democratization.

It is also worth discussing briefly three additional caveats. First, it is important to be clear about the composition of the relevant demos which is owed democratic standing of equal participation, accountability, and public justification. We have suggested that those individuals affected by the exercise of authority across and beyond the state are entitled to democratic rights. This fits well with the recent work on global democratization as it tracks current scholarship on how multiple demoi of affected agents can emerge beyond the state. ${ }^{37} \mathrm{ICs}$, on this view, may provide one pathway for the coalescence of demoi, and we bring out these formations in our analysis. Understanding how ICs can contribute to the formation of relevant demoi by connecting individuals to sites of public power requires sustained empirical analysis focusing on design and institutional relationships between ICs and other actors in world politics.

Second, it might also be contended that ICs are important for the legalization of world politics, but are not the appropriate institutional structures through which democratization should be promoted. It is a key point of this article that the global democratizing potential of ICs should be judged by looking at their role in the wider system. ICs can themselves be sites of authority that citizens are able or unable to participate in, but they can also curtail the authority of other national and international bodies. Given that global democratization is embryonic, it remains important to have an open conception concerning what role ICs may play. ${ }^{38}$ By focusing on ICs both as sites of authority and institutions embedded in a wider system, we are able to understand how ICs operate within a broader division of labour that either promotes or impedes global democratization.

\footnotetext{
${ }^{36}$ Eva Erman, 'In Search of Democratic Agency in Deliberative Governance', European Journal of International Relations, 19:4 (2012), pp. 847-68.

${ }^{37}$ Macdonald and Macdonald, 'Non-Electoral Accountability'. However, c.f. Shaffer, 'The boundaries of transnational democracy'; Bohman, 'Democratising the Global Order'; Laura Valentini, 'No Global Demos, No Global Democracy? A Systematization and Critique', Perspectives on Politics, 12:4 (2014), pp. 789-807.

${ }^{38}$ Or, to use Robert Goodin's phrase, global democracy is 'in the beginning'. See Robert Goodin, 'Global Democracy: In the Beginning', International Theory, 2:2 (2010), pp. 175-209.
} 
Finally, there are obvious connections between the increasing prominence of ICs and debates over the constitutionalization (or lack thereof) of international law. ${ }^{39}$ While some scholars see emergent legal constitutionalism taking place in world politics, others see increasing fragmentation and pluralism of legal orders and values. ${ }^{40}$ Although we are certainly witnessing an upsurge in the number and authority of ICs and other IOs, the literature is divided on the democratic potential of each pathway. Some authors suggest that global democracy is predicated on a strong rule of law safeguarded by constitutionalism, while others suggest that democratic values can emerge (or even thrive) under pluralism. ${ }^{41}$ Although this article does not directly engage these debates, we are interested in whether or not different design features of ICs can promote or impede democratic values beyond the state. Looking at our three different values, mapping the design of ICs, and unpacking the effects in practice we provides instructive evidence for both constitutionalists and pluralists as they seek to determine which pathway is unfolding and the related normative (i.e. democratic) potential.

\section{The Role of International Courts}

Today ICs are a prominent and influential element of governance across and beyond the state. International courts are here defined as permanent international judicial bodies that meet the following criteria: (1) decide the question(s) brought before them on the basis of international law, (2) follow pre-determined rules of procedure, (3) issue legally binding outcomes, (4) are composed of independent members, and (5) require at least one party to a dispute is a state or an

\footnotetext{
${ }^{39}$ See, for instance, Antje Wiener, Anthony F Lang, James Tully, Miguel Poiares Maduro, Mattias Kumm, 'Global constitutionalism: Human rights, democracy and the rule of law', Global Constitutionalism, 1:1 (2012), pp. 1-15. See also Karolina Milewicz, André Bächtiger and Arne Nothdurft, 'Constitutional pluralism or constitutional unity? An empirical study of international commitment (1945-2007)', Review of International Studies, 36:2 (2010), pp. 305-36.

${ }^{40}$ For overviews, see: Jeffrey L Dunoff and Joel P Trachtman (eds.), Ruling the World? Constitutionalism, International: Law, and Global Governance (Cambridge: Cambridge University Press, 2009); Gunther Teubner and Andreas Fischer-Lescano, 'Regime-Collisions: The Vain Search for Legal Unity in the Fragmentation of Global Law', Michigan Journal of International Law, 25:4 (2004), pp. 999-1045. See also Paul Schiff Berman, 'Global Legal Pluralism', Southern California Law Review, 80:6 (2007), pp. 1155-237.

${ }^{41}$ On the former, see Bardo Fassbender, 'We the Peoples of the United Nations: Constituent Power and Constitutional Form in International Law', in Neil Walker and Martin Loughlin (eds.), The Paradox of Constitutionalism: Constituent Power and Constitutional Form (Oxford: Oxford University, 2007), 269-90. On the latter, see Krisch, Beyond Constitutionalism.
} 
international organization. ${ }^{42}$ In recent years, the number of international courts has grown significantly. Figure 1 illustrates the expansion of ICs over time. Only one IC, the International Court of Justice (ICJ), existed in $1950 .{ }^{43}$ By 1990, there were a total of six ICs. ${ }^{44}$ The number of ICs peaked in 2006, when there were twenty-four. After the disbanding of the Tribunal of the Southern African Development Community (SADC) Tribunal in 2010, there were twenty-three international courts at the end of 2014. In addition to the numerical increase, ICs merit attention when examining world politics because they often play active and important roles in different issue areas, including the environment, trade, human rights, and armed conflict.

\footnotetext{
${ }^{42}$ Cesare Romano, Karin Alter and Yuval Shany, 'Mapping International Courts and Tribunals, the Issues and Players', in Cesare Romano, Karin Alter and Yuval Shany (eds.), The Oxford Handbook of International Adjudication (Oxford: Oxford University Press, 2013), p. 6. Permanence is not defined by whether the court itself is permanent, but whether the judges sit permanently and are not selected ad hoc by the parties to a dispute. Cesare Romano, 'A Taxonomy of International Rule of Law Institutions', Journal of International Dispute Settlement, 2:1 (2011): p. 262.

${ }^{43}$ Prior to 1950, two international courts existed: the Permanent Court of International Justice (later replaced by the ICJ), and the Central American Court of Justice (operational 1908-1918). Non-permanent international judicial proceedings prior to 1950 included the Nuremburg Trials (1945-1946), the Tokyo Trials (1946-1948), the ad hoc dispute settlement system of GATT established in 1947, and the Permanent Court of Arbitration established in 1899. ${ }^{44}$ These six courts were the Andean Tribunal of Justice, the Benelux Court of Justice, the European Court of Justice (now the Court of Justice of the European Union), the International Court of Justice, the European Court of Human Rights, and the Inter-American Court of Human Rights.
} 


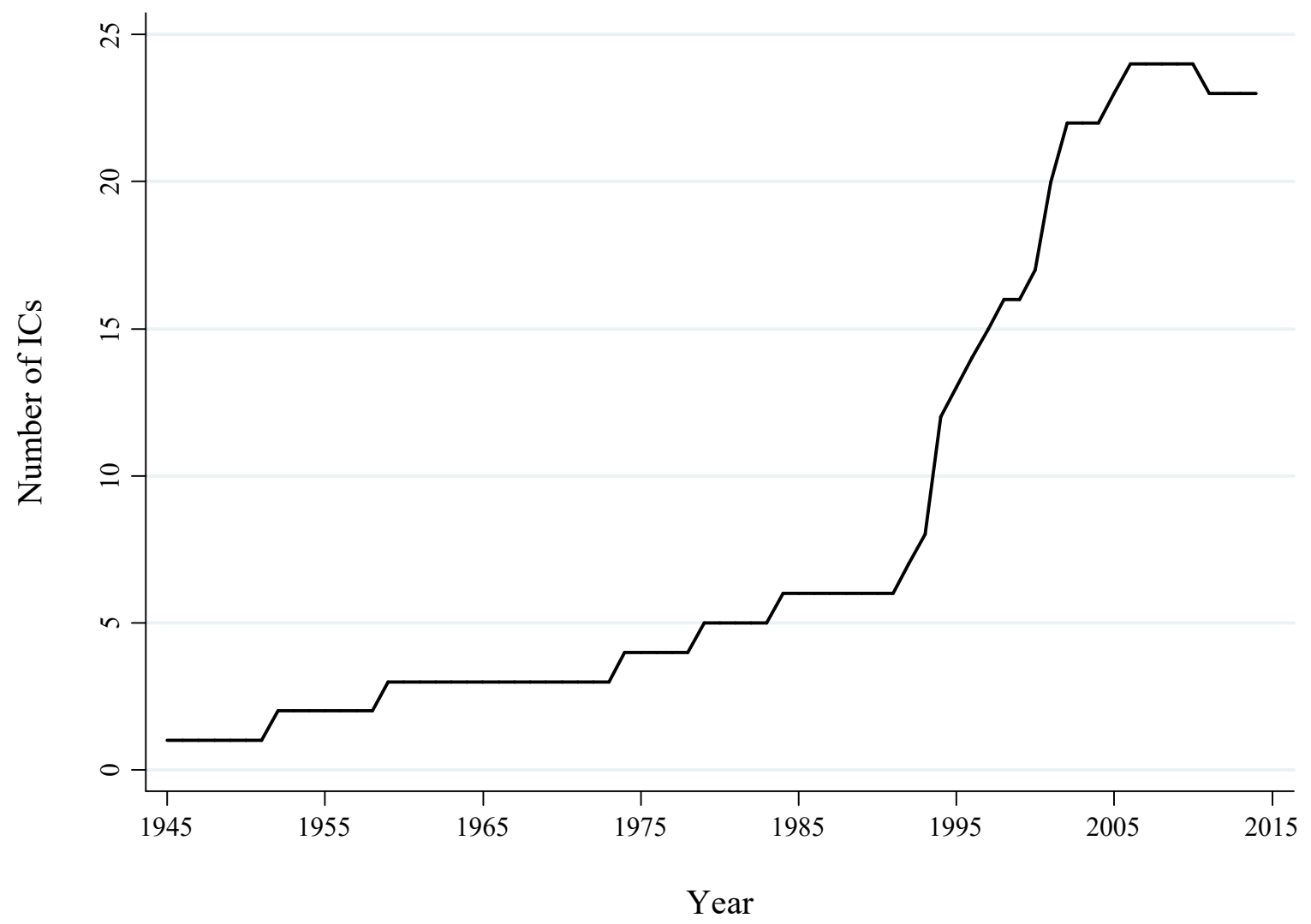

Figure 1. Number of ICs over time, 1945-2014

Given that global democratization involves giving affected individuals and collectives a say in the rules that govern their lives, there are several specific reasons for looking at ICs. First and foremost, ICs are central to dispute settlement in international relations. While ICs were traditionally designed only to settle disputes between state parties, today their role often extends to include disputes between private parties and states (e.g., human rights courts tend to have jurisdiction over disputes between private actors and a state). Even when disputes do not include non-state parties, the outcomes of the judicial proceedings can have profound effect on individuals and collectives. ${ }^{45}$ In this vein, ICs have been called upon to adjudicate an unprecedented number of disputes. Alter concludes that through 2011, there have been a total of 37,236 binding rulings issued by ICs in contentious cases. ${ }^{46}$

\footnotetext{
${ }^{45}$ Nienke Grossman, 'The Normative Legitimacy of International Courts’, Temple Law Review, 86:1 (2013), pp. 61106.

${ }^{46}$ Alter, The New Terrain of International Law, p. 75.
} 
Second, beyond settling disputes, ICs fulfill several other roles that affect international and national authority. Laurence Helfer identifies several, including "exercising constitutional, enforcement, and administrative review; stabilizing normative expectations and legitimating the exercise of public authority; improving state compliance with primary legal norms; engaging in judicial lawmaking to clarify or expand substantive obligations; and enhancing the legitimacy of international norms and institutions, including of ICs themselves. ${ }^{, 47}$ As such, ICs may promote the goals of an IO or regime. The Court of Justice of the European Union (CJEU) has been central to the institutionalization of regional integration in Europe. ${ }^{48}$ Similarly, the WTO's Dispute Settlement Mechanism has facilitated trade relations globally and is often viewed as one of the most successful elements of the WTO ${ }^{49}$ Research on international criminal tribunals also suggests they can deter violence and contribute to the building of domestic democratic processes. ${ }^{50}$

Third, in conjunction with interlocutors, ICs can improve state compliance with international commitments and thus help to address global problems. We can see that the European Court of Human Rights (ECtHR) and Inter-American Court of Human Rights (IACtHR) have contributed to reforms in law and policy governing the rights of individuals. ${ }^{51}$ For example, Helfer and Voeten have shown the transformative effects of the ECtHR on LGBT rights across Europe. ${ }^{52}$ These issues bear directly on the rules governing individuals.

Fourth, ICs contribute to world politics by clarifying and developing international legal obligations. Through the process of legal interpretation and adjudication, ICs can transform international law through sometimes incremental, minor forms of legal clarification and at other times through more active lawmaking. For example, the ICJ and the International Criminal

\footnotetext{
${ }^{47}$ Laurence Helfer, 'The Effectiveness of International Adjudicators', in Romano, Alter and Shany, (eds.), The Oxford Handbook, p. 464.

${ }^{48}$ Anne-Marie Burley and Walter Mattli, 'Europe before the Court: A Political Theory of Legal Integration', International Organization, 47:1 (1993), pp. 41-76.

${ }^{49}$ Chad Bown, 'On the Economic Success of GATT/WTO Dispute Settlement', Review of Economic Statistics 86:3 (2004), pp. 811-823.

${ }^{50}$ Hyeran Jo and Beth Simmons, 'Can the International Criminal Court Deter Atrocity?' (2014) Available at SSRN: http://dx.doi.org/10.2139/ssrn.2552820v; Lara Nettelfield, Courting Democracy in Bosnia and Herzegovina: The Hague Tribunal's Impact in a Postwar State (Cambridge: Cambridge University Press 2013).

${ }^{51}$ Courtney Hillebrecht, Domestic Politics and International Human Rights Tribunals: The Problem of Compliance (Cambridge: Cambridge University Press, 2014).

${ }^{52}$ Laurence Helfer and Erik Voeten, 'International Courts as Agents of Legal Change: Evidence from LGBT Rights in Europe', International Organization, 68:1 (2014), pp. 77-110.
} 
Tribunal for the former Yugoslavia (ICTY) have asserted that laws of war apply to internal conflicts. ${ }^{53}$ Likewise, the CJEU extended the scope of EU law to include human rights.

Finally, ICs - especially those with compulsory jurisdiction and access for private litigants - have strengthened an international rule of law and contributed to the judicialization of world politics. ${ }^{54}$ These are only a few of the ways we can observe the effects of international courts on transnational authority. Against this backdrop, we consider if ICs can promote global democratization by focusing on how ICs are designed to integrate the principles of equal participation, accountability and public justification in world politics.

\section{International Courts, Institutional Design, and Global Democratization}

\section{Equal Participation}

ICs can bolster global democratization by engendering possibilities for individuals to participate in how transnational authority is exercised. To assess how ICs foster or impede equality of participation, we analyze the institutional design features that condition access to the courts. As Cichowski argues, an "important factor in understanding how courts can change participatory politics is the degree of access the public has to legal institutions". ${ }^{55}$ Formal rules governing access for stakeholders, in other words, are the institutional condition to participation. Recent research has noted that access correlates strongly with participation and has been an essential activity of international courts. ${ }^{56}$ Moreover ICs with non-state actors' access tend to have the majority of their cases filed at the request of non-state actors, and many of these ICs also have larger caseloads than their counterparts with less access. ${ }^{57}$ We draw from our original dataset on formal rules of ICs to examine how international courts enable opportunities for participation. We look at the data on formal rules that regulate private, non-state actors' access to international

\footnotetext{
${ }^{53}$ Eve La Haye, War Crimes in Internal Armed Conflict (New York: Cambridge University Press, 2008).

${ }^{54}$ Yuval Shany, 'No Longer a Weak Department of Power? Reflections on the Emergence of a New International Judiciary', European Journal of International Law, 20:1 (2009), pp. 73-91. See also Alter, The New Terrain of International Law.

${ }^{55}$ Rachel A. Cichowski, 'Courts, Rights and Democratic Participation', Comparative Political Studies, 39:1 (2006), p. 55. For a longer discussion, see Rachel A. Cichowski, The European Court and Civil Society: Litigation, Mobilization and Governance (New York: Cambridge University Press, 2007).

${ }^{56}$ See Alter, The New Terrain of International Law; Cichowski, 'Courts, Rights and Democratic Participation'.

${ }^{57}$ Robert O. Keohane, Andrew Moravcsik, and Anne-Marie Slaughter, 'Legalized Dispute Resolution: Interstate and Transnational', International Organization, 54: 3 (2000), pp. 457-488.
} 
judicial proceedings. All ICs that have been in operation between 1945 and 2015 are included $(\mathrm{N}=24) .{ }^{58}$ The coding of access rules is based on the treaties and protocols establishing international courts, the rules of procedures of ICs, as well as some case law that established new access measures (which applies only in a few instances). Informal access options are excluded from the dataset because they are not dimensions of institutional design. Nevertheless, informal access may provide important modes of participation (discussed below).

There are four general types of formal rules that regulate access to international courts. ${ }^{59}$ These rules govern who can participate in judicial proceedings and in what capacity. The first type of rule addresses whether private, non-state actors can act as a direct litigant. Rules that allow stakeholders to become direct litigants are those that grant them opportunity to directly file a petition to a court to have a complaint heard by the court. Several courts are designed to grant stakeholders privileges to participate as a direct litigant, including the ECtHR, the Andean Tribunal of Justice (ATJ), the Central American Court of Justice (CACJ), among others.

Second, there are rules governing indirect litigants which specify whether private, nonstate actors can become a litigating party through referral of their case to an IC by a public authority. These rules differ from direct litigant access, where a stakeholder can directly petition an IC, because the stakeholder has access indirectly through a referral mechanism. Such rules include instances where a stakeholder can become an indirect litigant through a referral by a national court. Rules granting access as an indirect litigant through a national court referral are common to many regional trade courts, and are best exemplified by the CJEU's preliminary ruling procedure. Similarly, indirect litigant access can be defined by rules that require an intergovernmental commission, in combination with the acceptance of the court's jurisdiction by the relevant member state, to refer a case to the court. This form of indirect litigant access is common to international human rights courts. For example, six states have accepted the jurisdiction of the African Court of Human and Peoples' Rights (ACtHPR) to review an individual petition. A similar procedure exists for the IACtHR, as well as for the ECtHR prior to 1998.

\footnotetext{
${ }^{58}$ Our sample of ICs corresponds with Alter's; see Alter, The New Terrain of International Law. Appendix 1 provides a complete list of the ICs.

${ }^{59}$ Previous data on access to ICs do not cover all four types. When speaking of international criminal tribunals one might also victim access, such as offering testimony. We do not include this in the coding because it does not have a direct equivalent in the non-criminal tribunals.
} 
The third type of rule to govern access, and thus act as an institutional condition to participation, are those that regulate whether private, non-state actors can act as a third party in a case before an IC. Third parties can either be interveners or amicus curiae. While the privileges of an intervener are different from amicus, these are similar in that they offer a non-litigant the opportunity to voice their position on a case to the court. Many ICs provide third party privileges to stakeholders, including the IACtHR, the CJEU, and the ECtHR.

A fourth type of rule governing access to ICs regulates whether stakeholders can observe court hearings. This type of rule is specified by provisions that determine if an IC's oral hearings are to be held in public, thus allowing stakeholders to observe the proceedings of that IC. ${ }^{60}$ Many ICs allow for the public to observe hearings as a general rule. Yet, where the general rule is for public hearings, there are most often exceptions for closed proceedings. For example, the Statute of the International Court of Justice states that "[T] he hearing in Court shall be public, unless the Court shall decide otherwise, or unless the parties demand that the public be not admitted" (Article 46). Conversely, some ICs, such as the WTO panels and Appellate Body, operate with the general rule that proceedings are closed, and thus restrict private, non-state actors' access to judicial proceedings. ${ }^{61}$

\footnotetext{
${ }^{60}$ The connections between public justification and public participation rights are expanded upon below. Observer status, though, is a good example of how different democratic values intersect in supportive ways.

${ }^{61}$ Proceedings of the WTO AB can be open to the public upon agreement of the disputing parties. Otherwise, proceedings are closed to the public. Ruth Mackenzie, Cesare Romano, Philippe Sands, and Yuval Shany, The Manual on International Courts and Tribunals (Oxford: Oxford University Press, 2010), pp. 88-89.
} 


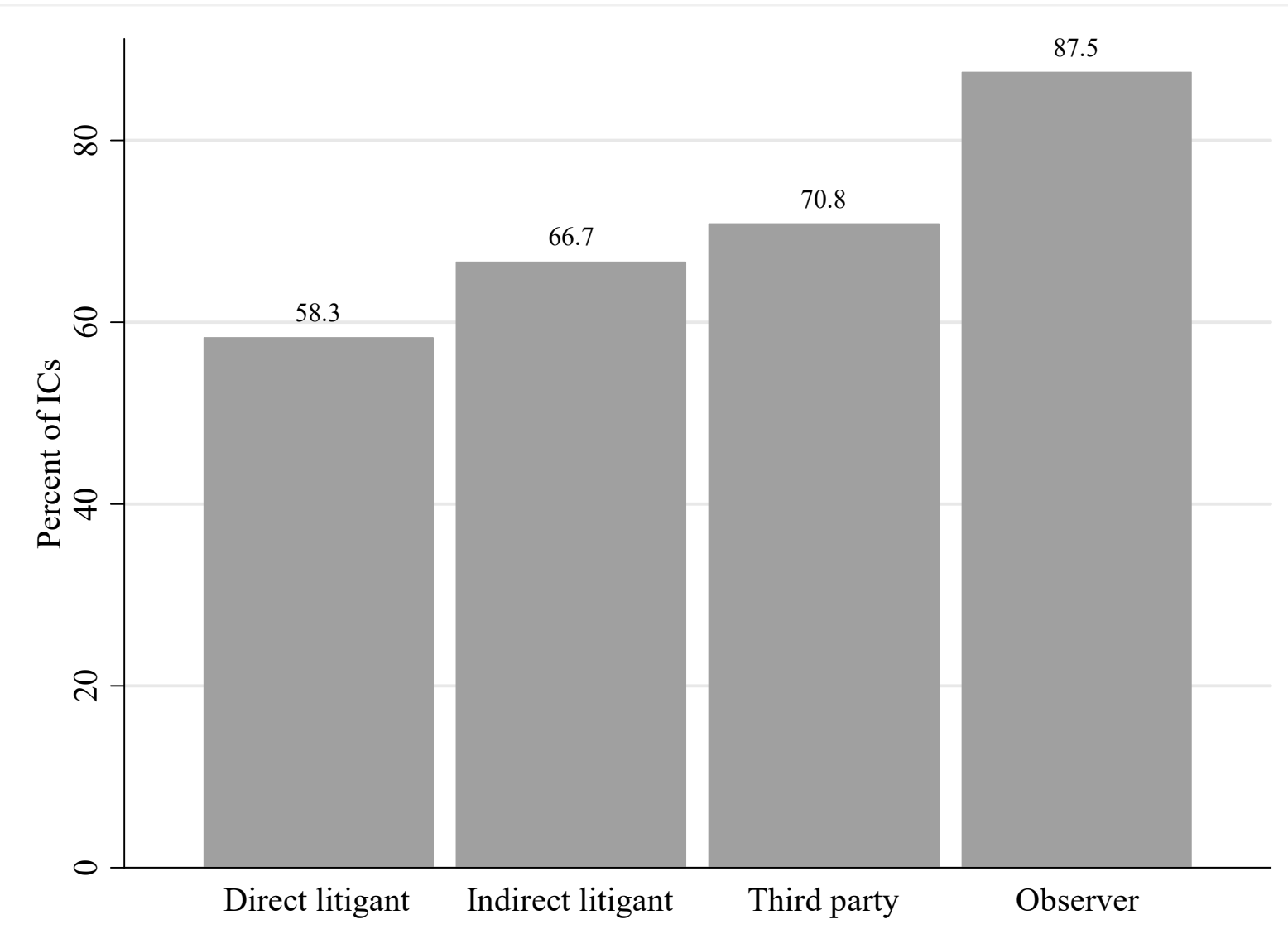

Figure 2. Percentage of international courts with stakeholders access (by type, 2015) $(\mathbf{N}=\mathbf{2 4})$

Figure 2 illustrates the percentage of international courts that feature each of the four types of access as of $2015 .{ }^{62}$ As the figure shows, most ICs (87.5\%) operate with the general rule that hearings are held in public, and thus allow private non-state actors to participate as observers. In fact, only three ICs do not have a general rule that oral proceedings of the court are to be held in public - the WTO panels and Appellate Body (AB), the Benelux Court of Justice (BCJ) and the Mercosur Permanent Review Tribunal (PRT). On the other hand, direct litigant privileges are the least common form of access to ICs. Today, more than half (58.3\%) of international courts are designed with access for stakeholders to participate as direct litigants.

\footnotetext{
${ }^{62}$ In accord with most comparative research on international courts, the SADC Tribunal is included in this figure based on its status in 2010, even though its operation has since been suspended. See Appendix for information on how each IC is coded on each of the four types of access. Supplementary appendix lists all sources and specific provisions coded.
} 
Direct litigant access is usually featured by regional trade courts. The ECtHR also features this form of access. Our data also reveal that all 24 ICs feature at least one type of access, six ICs feature three types, and nine feature all types of access (not shown).

These various access provisions provide affected parties with opportunities for participation. First, direct and indirect litigant access can enable stakeholders to participate in shaping public agendas in world politics. The ability to shape public agenda can be viewed as a form of democratic participation. ${ }^{63}$ Direct and indirect litigants shape the agenda of ICs because petitioning a court contributes to what issues are on its docket. Individuals' and societal groups' petitions to ICs, either directly or indirectly, have transformed the agendas of ICs in several instances. For example, direct and indirect litigants have put human rights issues on the dockets of regional trade courts. This has occurred for the East African Court of Justice (EACJ).$^{64}$ Recent petitions brought before the Caribbean Court of Justice (CCJ) have brought human rights issues to the original jurisdiction of the court. ${ }^{65}$ Similarly, referrals to the CJEU led to women's rights entering into the policy domain of the European Union and the CJEU. ${ }^{66}$

In other words, the participation of individuals and groups in international judicial proceedings, especially as litigants, contributes to an IC's agenda in ways that states could not, or would not. Private litigants have incentives to bring claims against non-compliant states, whereas states can have disincentives to do so. This opens up the possibly to mitigate the democratic deficit exacerbated by cross-national spillovers. Concerns for retaliation can prevent states from filing claims against fellow member states. Citizens, however, have incentives to do so, especially when they have seen only blockage through other channels of mobilization. ${ }^{67}$ Indeed, it is questionable whether many issues would have come to international courts if it were not for the opportunities presented by access.

While participation as direct and indirect litigants contributes to shaping an IC's agenda, the democratizing effects on world politics are much broader. This occurs in several ways. First, litigation before ICs can serve as a catalyst for mobilization and participation in other domestic

\footnotetext{
${ }^{63}$ Robert Dahl, Dilemmas of Pluralist Democracy (New Haven: Yale University Press, 1982), p. 6.

${ }^{64}$ James T. Gathii, 'Mission creep or a search for relevance: the East African Court of Justice's human rights strategy', Duke Journal of Comparative and International Law 24: 2 (2013), pp. 249-296.

${ }^{65}$ Maurice Tomilson v Trinidad and Tobago \& Belize. [2014] CCJ 2 (OJ); Shanique Myrie v. Barbados. [2013] CCJ

3 (OJ).

${ }^{66}$ Cichowski, The European Court and Civil Society.

${ }^{67}$ Margaret Keck and Kathryn Sikkink, Activists Beyond Borders: Advocacy Networks in International Politics (Ithaca: Cornell University Press, 1998).
} 
settings. Second, it can also lead to changes in international rules. For example, the CJEU's early rulings on women's rights contributed to mobilization of civil society organizations and secondary legislation by the European Union governing gender equality rights and environmental protection. ${ }^{68}$ Similarly, we have seen how the early referrals to the IACtHR on enforced disappearances preceded and contributed to later international efforts to establish binding law on the prohibition of enforced disappearances. Thus, direct and indirect litigant privileges enable citizens to participate in defining what lies on the agenda of international courts, and thus on broader public agendas in world politics.

Direct and indirect litigant access, as well as third party privileges, also allow for democratic participation by presenting stakeholders with the opportunity to present a voice in decision-making. These three forms of access give affected persons opportunities to present both factual information and legal arguments as well as introduce valuable perspectives that can contribute to decision-making by ICs. Stakeholders are often well-equipped to contribute to the information that judges have to make their decisions for two reasons. On one hand, non-state stakeholders have valuable resources that judges or state parties do not. In particular, these resources include scientific expertise, local knowledge and sector-specific information. On the other, stakeholders contribute to the representation of a diverse set of societal perspectives that are otherwise missing from judicial proceedings. As Bogdandy argues, courts are not representative institutions because of the requirements of independence and impartiality. ${ }^{69}$ Nevertheless, judges should consider societal convictions and interests when adjudicating. Third party access, especially, can serve as a vehicle for these convictions and interests to enter into the judicial process. Williams and Woolaver find that "[A]micus can be very useful in ensuring that the perspective of these groups [victims and groups within society] is heard" during international criminal tribunals' proceedings. ${ }^{70}$ Thus, third party access may compensate for an IC's inability to be a representative institution and help to integrate societal perspectives into judicial decisionmaking.

Access to observe the hearings of international courts can also bolster participation. While seemingly minor, open proceedings enable international judicial proceedings to become

\footnotetext{
${ }^{68}$ Cichowski, The European Court and Civil Society.

${ }^{69}$ Bogdandy, 'The Democratic Legitimacy of International Courts', p. 370.

${ }^{70}$ Sarah Williams and Hannah Woolaver, 'The Role of Amicus curiae before International Criminal Tribunals', International Criminal Law Review, 6:2 (2006), pp. 185.
} 
salient to the broader public. Public observers are likely to include media, bringing an international decision-making process into the public sphere. Similarly, third party access can improve democratic participation by also building a public sphere around international court proceedings. $^{71}$

While IC access rules can foster participation beyond the state, participation may in practice be impeded by various issues which inhibit the realization of global democratization in practice. Access to ICs, especially as a litigant, requires that some personal interest in a dispute be demonstrated and that the dispute meet specific admissibility or standing requirements. This is distinct from other forms of democratic participation, which generally only hinge on citizenship, rather than interest. ${ }^{72}$ While access rules treat individuals equally based on citizenship, it is then restricted to those individuals who can demonstrate an interest while fulfilling admissibility criteria. This clearly restricts the scope of litigants to those capable of articulating how their interests are affected. While this is problematic in some ways, it also speaks to the potentiality of ICs in helping delineate demoi beyond state boundaries.

Equal participation through ICs is also impeded in practice by factors such as monetary and epistemic resources, or even physical proximity to an IC which structurally disadvantage some individuals and groups more than others. At the domestic level, litigation is costly and demands knowledge of the law as well as expertise in how to navigate the legal system. International litigation is also demanding of resources, in addition to being extremely remote from the average person. These factors - funding, knowledge, and geography - can all substantively undermine the potential of democratic participation by affected parties. Some additional design features, such as a traveling court (for example, a feature of the Caribbean Court of Justice) or legal aid, can however compensate for such structural disadvantages and be used to improve the opportunities and equality of participation featured by ICs. Similarly, some may argue that those societal actors who participate through courts lack democratic credentials. While this may be the case, judges usually have the discretion to determine whether such actors' views should be disregarded.

\footnotetext{
${ }^{71}$ Robyn Eckersley, 'A Green Public Sphere in the WTO?: The Amicus Curiae Interventions in the Transatlantic Biotech Dispute', European Journal of International Relations, 13:3 (2007), pp. 329-356.

${ }^{72}$ Anna Holzscheiter, 'Representation as power and performative practice: Global civil society advocacy for working children', Review of International Studies, (forthcoming), DOI: http://dx.doi.org/10.1017/S0260210515000145.
} 
Despite possible shortcomings, access to ICs provide an important means of participation in world politics. There is also previous scholarship suggesting that private non-state actors are in practice accessing ICs to challenge the exercise of transnational authority. ${ }^{73}$ It remains clear, however, that the design of access rules affect the terms of participation. Direct and indirect litigation enable deeper participation which can extend to agenda-setting. Alternately, third-party and observer status is a more limited form of participation, perhaps enhancing representation. When these various access designs are featured in conjunction, participation is heightened even further. As such, the design rules of ICs on access effects the equality of participation offered to individuals. Thus ICs can improve equal participation in a shift toward global democratization, but the mechanisms of access condition the depth and equality. ${ }^{74}$ Moreover, while design rules condition the attainment of democratic participation through ICs, additional epistemic, geographic, and resource-based factors enable and constrain the practice of global democratization.

\section{Accountability}

ICs can also bolster the practice of accountability in global governance by safeguarding and ensuring that transnational authority is exercised according to established standards vis-à-vis affected agents. Grant and Keohane suggest that courts, including international courts, are a type of accountability mechanism. ${ }^{75}$ We agree with this assessment and identify more specifically how they can be used to hold states and international actors and institutions to account, thus facilitating global democratization.

ICs have two types of powers that enable them to serve as an accountability mechanism in world politics and grant democratic control to affected parties. First, some ICs have been designed with the power of administrative review. These ICs "have jurisdiction to assess the validity of administrative decisions and a corresponding authority to annul illegal administrate

\footnotetext{
${ }^{73}$ Several ICs have seen a temporal increase in their dockets as a result of direct and indirect access. For example, see Cichwoski, 'Courts, Rights and Democratic Participation'; Alter, The New Terrain of International Law.

${ }^{74}$ While we argue that access to ICs fosters participation beyond the state, and thus global democratization, some scholars have argued that these same features can improve the internal legitimacy of ICs as well. Armin von Bogdandy and Ingo Venzke, 'On the Democratic Legitimation of International Judicial Lawmaking', German Law Journal, 12:5 (2011), pp. 1341-1370. See also Grossman, 'The Normative Legitimacy of International Courts'.

${ }^{75}$ Grant and Keohane, 'Accountability and Abuses of Power'.
} 
actions". ${ }^{76}$ International administrative review is one way in which state and IO authority can be checked and protected against arbitrary decisions. Specifically, ICs with administrative review assess whether administrative decisions abide by procedural rules and correctly apply the law. In practice, international administrative review by an IC is exercised when a court declares an administrative decision to be illegal and, in some instances, requires compensation for the wronged. We are interested in both review of international and national administrative decisions as both cross-national spillovers and the authority of IOs can contribute to the global democratic deficit. However, the degree to which ICs have the power of administrative review varies. While some ICs have authority to annul both international and national administrative decisions, others have only one form of administrative review and some have no delegated administrative review.

Second, some international courts have been designed to have the power of constitutional review, or the jurisdiction to assess the validity of legislative acts. ${ }^{77}$ As many IOs are able to produce legislative output (e.g., resolutions, directives, and regulations), constitutional review can play an important role in safeguarding that international legislative output does not conflict with higher order legal principles such as an IO's constitutive treaty, general principles of law, or human rights norms. ICs can also have the power to review and annul national law. The extent to which ICs have these constitutional review powers differs; some are designed with these powers while others are not. Those with the authority of constitutional review have been known to exercise this authority, albeit infrequently. ${ }^{78}$ Constitutional review by ICs allows stakeholders to challenge international and national legislation and when an IC finds in their favor the act is nullified.

\footnotetext{
${ }^{76}$ Alter, The New Terrain of International Law, p. 202.

${ }^{77}$ Ibid., p. 286. A prominent example of a case where an IC exercises international constitutional review is the Kadi case decided by the CJEU. Case C-402/05 P and C-415/05, P. Kadi and Al Barakaat International Foundation $v$. Council and Commission [2008] ECR I-6351.

${ }^{78}$ Ibid., p. 295.
} 
Admininistrative review of international actions

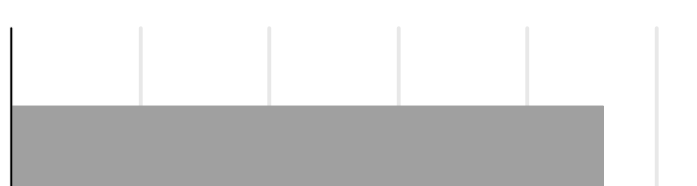

Administrative review of national actions

Constitutional review of international acts

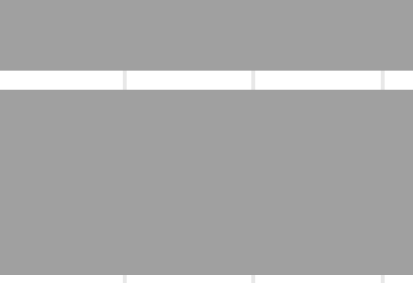

Constitutional review of national acts
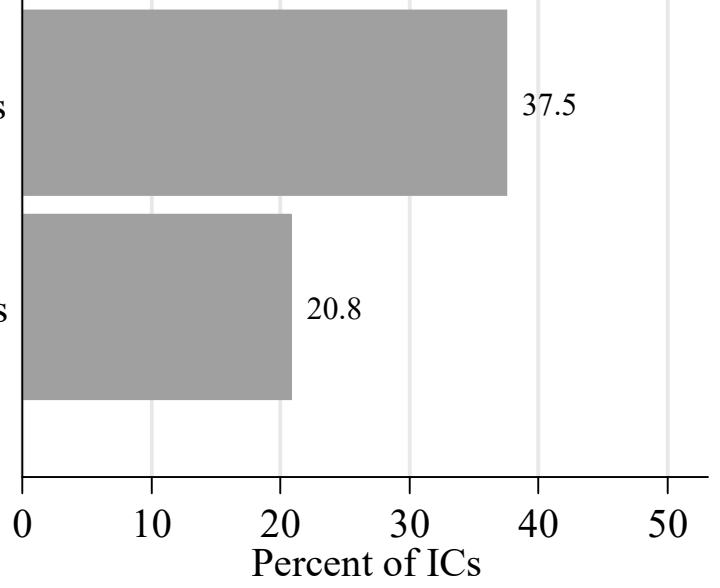

Source: Coding is based on Alter, The New Terrain of International Law.

\section{Figure 3. International Courts with Administrative and Constitutional Review ( $=24)$}

Figure 3 illustrates the distribution of ICs designed with administrative and constitutional review powers, and thus the potential to operate as an accountability mechanism where domestic and international decisions are evaluated. ${ }^{79}$ As Figure 3 shows several ICs (46\%) have the authority to review international administrative actions, and roughly $38 \%$ can review international legislative acts. Fewer ICs have the power to declare void the actions or acts of states. One-third of ICs can review the actions of national authorities, while $21 \%$ can review national legislative output. Regional courts embedded within regional economic and trade organizations are especially central to understanding how accountability is practiced through international courts. On the face of it, issues such as human rights are often outside of the accountability mechanisms provided by ICs because administrative and constitutional review

\footnotetext{
${ }^{79}$ See Appendix for more information.
} 
tends to be provided by regional trade courts. However, several regional trade courts have either been granted or expanded their jurisdiction to include human rights issues, including the EACJ, SADC Tribunal, CJEU, and others.

Where ICs do not have the authority of constitutional and administrative review, their ability to hold other sites of transnational authority accountable are formally limited. Nonetheless, despite not having explicit powers to nullify national administrative decisions, several courts exercise a form of administrative review in practice when declaring national authority has contravened international legal obligations. For example, the WTO DSM and international human rights courts hold states to account for laws, policies, and actions which may violate international trade law and international human rights law. ${ }^{80}$ ICs that can declare national administrative actions contravene international obligations, according to either substantive or procedural standards, act as a check on national authority. ${ }^{81}$ Also, while international criminal tribunals do not directly hold transnational authority to account (as they are mandated to hold individuals accountable), they indirectly ensure some kind of accountability for national authority (both as it is exercised within state borders and across), through the prosecution of heads of state and other actors who act as agents of the state.

When ICs can review the actions of domestic or international administrators or the validity of international legislative output, they have the potential to advance global democratization through practices of accountability. Many courts do have these powers, indicating that ICs can hold other IOs or states to account based on predetermined standards. When these powers are held in combination with access for private non-state actors, ICs are able to serve as an accountability mechanism that is available to individuals and societal groups. In fact, the powers of administrative and constitutional review most often coincide with access provisions. All ICs with administrative review have compulsory jurisdiction and access for direct and indirect litigants, meaning that individual stakeholders can use litigation before these international courts to challenge administrative decisions. ${ }^{82}$ Similarly, constitutional review is also common to ICs with compulsory jurisdiction and access for direct and indirect litigants. In most instances, constitutional review can be initiated by individual stakeholders.

\footnotetext{
${ }^{80}$ Alter, The New Terrain of International Law, pp. 210-211.

${ }^{81}$ Michael Ioannidis, 'A Procedural Approach to the Legitimacy of International Adjudication: Developing Standards of Participation in WTO Law,' German Law Journal, 2011, 12:5, pp. 1175-1202.

${ }^{82}$ Alter, The New Terrain of International Law, p. 202.
} 
As with equality of participation, though, the ability to hold international actors to account and curb arbitrary power through ICs does suffer from some pitfalls. First, as previously mentioned, non-state actors' use of ICs may be limited by factors such as monetary and epistemic resources. These limitations provide a substantive critique of global democratization by suggesting, as Dingwerth does, that issues of education and subsistence are required to make use of democratic procedures. While we agree with this, improvements in health, education, resource distribution, and so on can also be promoted by formal rules of accountability. ${ }^{83} \mathrm{In}$ other words, there is likely a mutually beneficial relationship between giving individuals formal rights of participation and accountability in ICs and the substantive improvement in life prospects for affected individuals that deserve consideration by designers.

Second, even when ICs are designed to have the power of administrative and constitutional review, they face many political constraints that limit the extent to which they utilize this power in practice. This can include the ability of other IOs to exercise informal forms of power over the judicial process of different ICs and intransigence on behalf of states to follow IC decisions. This is not a problem inherent to ICs, but rather an issue that afflicts the decisionmaking of all IOs. However, problems surrounding how informal power politics might contribute to the global democratic deficit certainly warrant more attention. This speaks to the role of ICs as part of a broader division of labour for global democratization. If IOs and states exercise informal power over the decision-making procedures or outputs of ICs, then their role as accountability wielder - through both administrative and constitutional review - is severely dampened. At the least we suggest that informal power between states, along with limitations to individuals, will be factors that determine how well the design rule of administrative and constitutional review play out in practice.

Third, not all international organizations fall within the purview of international courts, as defined here. This means that many sources of authority in global governance do not have corresponding accountability mechanisms similar to that of ICs. On the other hand, several international organizations have quasi-judicial processes or bodies that can in some ways hold international authority to account. For example, in the area of development, the World Bank has the Inspection Panel and the Asian Development Bank the Compliance Review Mechanism.

\footnotetext{
${ }^{83}$ Dingwerth, 'Global Democracy and the Democratic Minimum'.
} 
Despite these pitfalls, accountability in world politics is, we argue, greater with international courts than without, and thus ICs are critical for global democratization. Administrative and constitutional review powers are the core design features that enable international courts to offer a series of checks-and-balances on the use of arbitrary power by IOs and other state actors. Moreover, when these review powers can be initiated by individual stakeholders, as opposed to only states, the ability of an IC to serve as a democratic accountability mechanism is heightened by giving affected parties avenues to shape decisionmaking (and the interpretation of existing rules) beyond the state. This again indicates that institutional design is critical in bolstering accountability, strengthening the links between individual participation and accountability, and ensuring robust democratic practice beyond the state.

\section{Public Justification}

International courts may also contribute to global democratization through practices of public justification. As Habermas has consistently suggested, it is the public use and justification of reasoning which sits at the core of democracy. ${ }^{84} \mathrm{~A}$ characteristic of judicial decision-making is that judges explain the reasoning of their decisions and deliver their decisions publically. Even when judicial decisions are not elaborate in their reasoning, they nonetheless specify the legal basis for their decisions. ICs are no exception. In fact, ICs are often (though interestingly not always) required by a matter of their constitutive treaties or rules of procedure to make decisions public and identify the reasons of their decisions. As a consequence of these two requirements, ICs are uniquely positioned to bring public justification to the decisions that govern international politics.

To assess the extent to which ICs are designed to provide public justification, we draw again on our original dataset looking at ICs' formal rules on the publicity and reasoning of court judgments. Specifically, the dataset codes formal rules on: (1) whether decisions are to be delivered in a publically open session of the court, (2) if decisions are formally required to be published, at least in part, (3) whether decisions are to be reasoned, and (4) if separate

\footnotetext{
${ }^{84}$ Habermas, Between Facts and Norms.
} 
(concurring or dissenting) opinions can be issued by judges. ${ }^{85}$ Figure 4 shows what percentage of ICs feature each of these various rules.

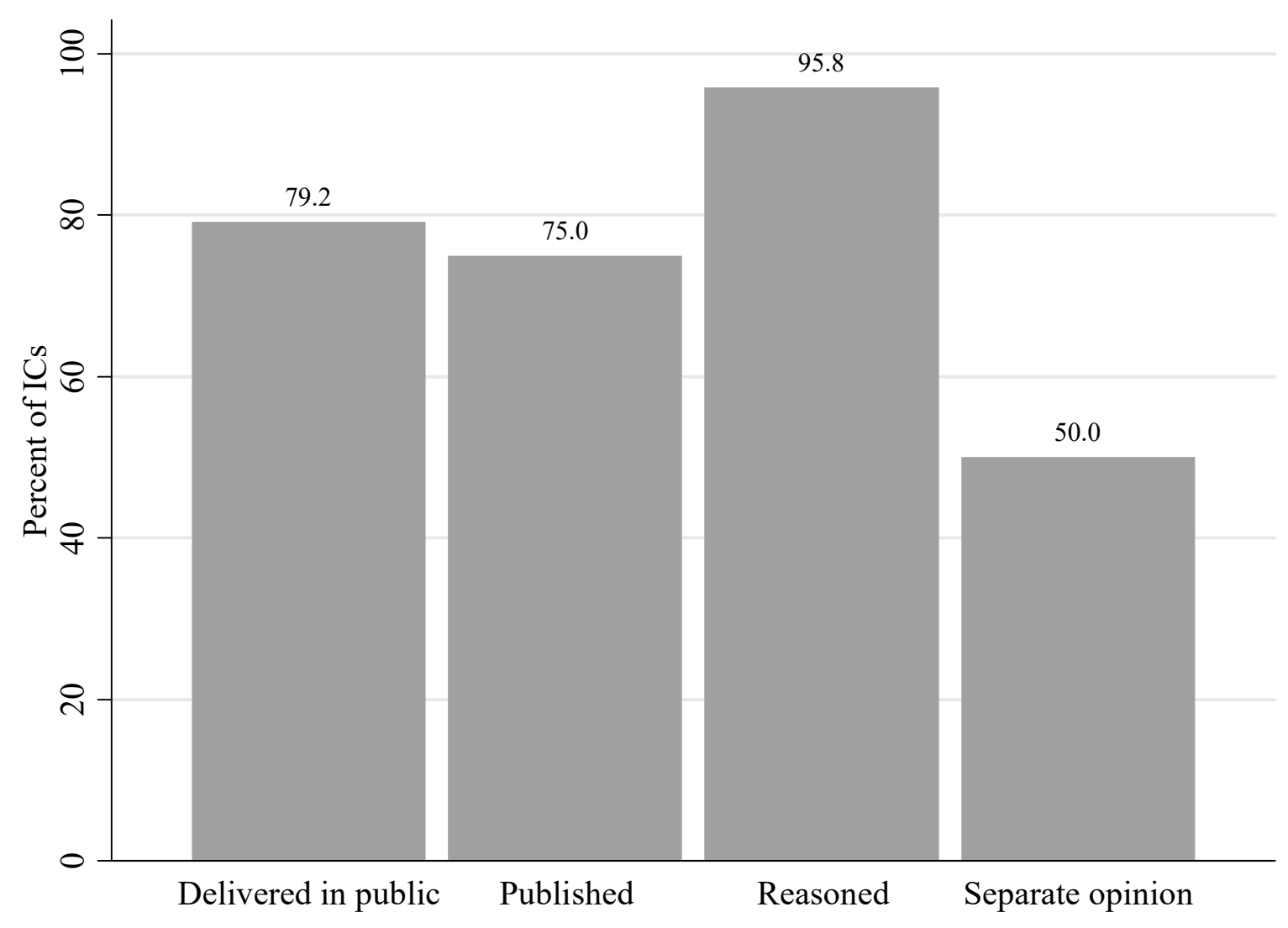

\section{Figure 4. Percentage of ICs with formal rules on publicity and reasoning of decisions} $(\mathrm{N}=\mathbf{2 4})$

As Figure 4 highlights, most ICs are formally required to make their decisions public in some manner. Seventy-nine percent of ICs are required to issue their decisions in a public session, while seventy-five percent must publish their decisions. In many instances, where one of the requirements of publicity is missing, it is compensated by a requirement to make their decisions public according to the other means. For example, the most recent version of the ECtHR's rules of procedure does not require that decisions be delivered in open court, yet decisions are required to be published. In fact, the only IC that does not have formal rules to

\footnotetext{
${ }^{85}$ See Appendix for information on how each IC is coded along these dimensions.
} 
issue decisions in public or to publish them is the WTO Appellate Body (AB). Yet, the WTO AB's reports are all publically available. Many courts also make their decisions public in practice through publication on their websites, despite the formal rules. This suggests that some informal practices can develop along democratic lines even if formal measures are not codified.

Having decisions made public is only one aspect of how ICs practice public justification. ICs, in conjunction with publically-issued decisions, give reasoned decisions. As Figure 3 shows, roughly $96 \%$ of ICs are required by formal rules to provide reasoning to their judgments. The one instance where this is not the case is the WTO AB (though the ad hoc panels are required to do so). Even without the formal requirement, however, the $\mathrm{AB}$ in practice does provide reasoned judgments. Reason-giving by ICs however varies in terms of quality as well as their mode and logic. In addition, ICs vary in whether separate opinions can be issued; figure 4 illustrates that half of ICs are allowed to issue separate (or dissenting) opinions.

We argue that the combination of making decisions public and explicating the reasoning of a decision advances the value of public justification in democratic ways. First, giving reasons for a decision is a device for informing the public of what the decision-maker is doing and why, while also controlling the use of discretion. When giving reasons decision-makers are "likely to make more reasonable decisions than he or she otherwise might and is more subject to public general surveillance". ${ }^{86}$ This is similar to the notion that open deliberation generates a "civilizing force' to avoid being hypocritical or exercising arbitrary power.

Second, the virtues of reciprocity and generalizability stand at the core of justified reason giving, especially in the deliberative democratic tradition. ${ }^{87}$ Providing reasons which take consideration of dissenting opinions is clearly an institutional embodiment of both reciprocity and generalizability by framing decisions and arguments in terms acceptable to other parties (reciprocity) and linked with precedent or other institutional laws (generalizability). In other words, reason-giving by courts resembles collective deliberation because it presents the public with a considered decision incorporating opposing positions. ${ }^{88}$ While a court considers opposing positions in deliberations, their expression in a court's official judgment may not be explicit. When a separate or dissenting opinion can be issued, there is greater guarantee that opposing or

\footnotetext{
${ }^{86}$ Martin Shapiro, 'The Reason Giving Requirement', University of Chicago Legal Forum, (1992), pp. 179-220.

${ }^{87}$ Forst, The Right to Justification.

${ }^{88}$ Laurence Helfer and Anne-Marie Slaughter, 'Towards a Theory of Effective Supranational Adjudication', Yale Law Journal, 107:2 (1997), p. 321.
} 
alternative viewpoints will be expressed. While there is some argument to whether separate and dissenting opinions can destabilize international adjudication, scholars have argued that separate or dissenting opinions improve reason-giving. ${ }^{89}$

Third, the reasoning offered - and the scope of judicial decisions - may also catalyze public discussion. Sunstein argues that, "case-specific judgments operate as a kind of 'remand' to the public for further proceedings, at least in the sense that they do not foreclose those proceedings and may even spur them through the visibility of court decisions." 90 ICs are often limited to case-specific judgments, especially when their judgments are not binding on parties other than the litigants. That said, the reasoned judgments provided by courts might frame future public debates, if not public decisions.

Again, there are limitations to this value. A pitfall of court-based public justification is that reason-giving is often embedded in an inaccessible legal discourse, and thus may not always be directly intelligible for the broader public. Affected individuals are often unable to access or decipher complex legal decisions. This makes is harder for affected parties to understand the ramifications of IC decisions. As such, the broader effects of reason giving are conditioned by the public dissemination and translation of court judgments. Publically-issued decisions and publication are thus crucial to the ability of ICs to incorporate the value of public justification.

Second, the actual deliberative quality of public decisions is typically not scrutinized closely. Consequently, judicial reasoning may be shaped by strategic negotiation among judges and their own policy preferences. The requirement of reason-giving and publicity can compensate for these pitfalls, and fosters decisions that are generalizable and reciprocal. In other words, the separate elements of public justification - publicity and reasoning - offer the most democratizing leverage when taken together because publicity helps to moderate overt strategic and particularistic decision-making. Moreover, the incorporation of dissenting opinions is also critical for ensuring that arguments are subjected to the give-and-take of deliberative democratic reasoning. Given that only $50 \%$ of ICs ensure that separate opinions can be issued, though, suggests that there is much more scope and leverage for ICs to enhance global democratization.

\footnotetext{
${ }^{89}$ J.H.H. Weiler, 'Epilogue: The Judicial Après Nice' in Gráinne de Búrca and J. H. H. Weiler (eds.), The European Court of Justice (Oxford: Oxford University Press, 2001), p. 225; Vlad Perju, 'Reason and Authority in the European Court of Justice', Virginia Journal of International Law 49:2 (2009), pp. 307-377.

${ }^{90}$ Cass Sunstein, 'Public Deliberation, Affirmative Action, and the Supreme Court', California Law Review, 84:4 (1996), p. 1183.
} 
Public justification, as we have shown here, can be a feature of institutional design. Moreover, it is one that is commonly embedded in the designs of ICs, enabling them to advance global democratization. The greater the provisions for publicity of decisions and reasoning, especially how dissenting views can and should be incorporated into judicial decision-making, the stronger the practice of public justification becomes and thus the greater the contribution ICs have for global democratization. As a result, the connections between public justification and the other democratic values - equal participation and accountability - run deep. This speaks to the need to think about ICs as part of a broader process of global democratization. Institutional rules can and should be designed in symbiotic ways. Public justification provides equal respect for individuals who participate as well as audiences who view the decision-making. Providing individual direct or indirect litigants with public reasons for decisions provides depth to the quality of equal participation. Public decisions on matters of administrative and constitutional review offer international actors a fair and transparent platform to understand the rationale of decision-making. Again this highlights the importance of ICs in a division of labour for global democratization. While given powers of constitutional and administrative review over other IOs and states, it is important to check this power of ICs (and not through the informal power of states and IOs that they are supposed to regulate). Providing avenues of access and reasoned justification goes a long way to safeguarding the emergence of global democratization.

\section{Conclusion}

In conclusion, we make three points. First, this article has explored if, how, and under what conditions ICs contribute to the emergence of democratic values beyond the state. Drawing from three prominent strands of democratic theory and a synthesis of recent literature, we found evidence that ICs help promote global democratization by: enhancing equality of participation for affected actors; holding other international actors to account thus dampening arbitrary power; and offering public reasoning. Our analysis did not presume that these three values were the correct values to regulate ICs or link ICs with global democratization..$^{91}$ But drawing from our dataset and supplemented with case-specific evidence, we have found strong evidence that ICs

\footnotetext{
${ }^{91}$ Instead we offered separate rationale for adopting these values, derived from democratic theory and recent work on global democracy.
} 
do embody these values beyond the state. That said, the relationship between all three values and ICs were contingent upon the canvassed features of institutional design and issues of implementation. We identified procedural and substantive limitations to the attainment of each value, thus suggesting that further conditions need to be met for global democratization to progress fruitfully. Ultimately, though, we suggest that global democratization is far from a chimera, but rather a tangible set of values that can be actively strived toward.

Second, the article speaks directly to the literature in international law on the democratic legitimacy of ICs themselves. Although space constrains a full exploration, authors such as Armin von Bogdandy, Ingo Venzke, Nienke Grossman, and many others have probed how the authority exercised by ICs can be democratically legitimated in the absence of an encompassing national framework. ${ }^{92}$ These authors often highlight the same features we have, especially access and public justification, as key to the internal democratic legitimacy of ICs. Our arguments here all speak to the fact that the authority of ICs can be democratically legitimated through equal participation of stakeholders, curbing arbitrary power, and providing public reasoning for decisions. But more importantly our paper also speaks to the role of ICs in the broader landscape of global democratization, the potential role they could play in a division of labour, and the factors inhibiting realization in practice.

Finally, the article has several limitations which provide future avenues for research. Democratically speaking, equal participation should be offered to those affected by decisions. Although we have touched upon the issue, future work should delve into more detail about who precisely is given rights of access to ensure that those most in need of participation and representation have their interests considered. This will speak to recent literature concerned with how multiple demoi emerge across and beyond the confines of the nation state. ${ }^{93}$ Likewise, accountability mechanisms should themselves be justified to those affected by decisions. Moreover the deliberative quality of public reasoning by ICs should be subject to greater scrutiny. Content analysis and other quantitative measures (such as the Discourse Quality Index)

\footnotetext{
${ }^{92}$ Bogdandy, 'The Democratic Legitimacy of International Courts '; Bogdandy and Venzke, 'On the Democratic Legitimation'; Grossman, 'The Normative Legitimacy of International Courts'.

${ }^{93}$ Valentini, 'No Global Demos'.
} 
offer ways forward on this front. ${ }^{94}$ It is through this type of in-depth analysis that the normative foundations of global democratization can be assessed with more rigour.

${ }^{94}$ Marco R Steenbergen, André Bächtiger, Markus Spörndli and Jürg Steiner, 'Measuring Political Deliberation: A Discourse Quality Index', Comparative European Politics, 1 (2003), pp. 21-48. 
Appendix:

\begin{tabular}{|c|c|c|c|c|c|c|c|c|c|c|c|c|c|}
\hline \multirow{2}{*}{ Court } & \multirow[t]{2}{*}{$\begin{array}{l}\text { Year in } \\
\text { operation }\end{array}$} & \multirow[t]{2}{*}{$\begin{array}{l}\text { Direct } \\
\text { litigant }\end{array}$} & \multirow[t]{2}{*}{$\begin{array}{l}\text { Indirect } \\
\text { litigant }\end{array}$} & \multirow[t]{2}{*}{$\begin{array}{l}\text { Third } \\
\text { Party }\end{array}$} & \multirow[t]{2}{*}{ Observer } & \multicolumn{2}{|c|}{$\begin{array}{c}\text { Administrative } \\
\text { review }\end{array}$} & \multicolumn{2}{|c|}{$\begin{array}{c}\text { Constitutional } \\
\text { Review }\end{array}$} & \multirow[t]{2}{*}{$\begin{array}{l}\text { Delivered } \\
\text { in public }\end{array}$} & \multirow[t]{2}{*}{ Published } & \multirow[t]{2}{*}{$\begin{array}{l}\text { Reasoned } \\
\text { opinion }\end{array}$} & \multirow[t]{2}{*}{$\begin{array}{l}\text { Separate } \\
\text { Opinion/ } \\
\text { Dissent }\end{array}$} \\
\hline & & & & & & $\begin{array}{l}\text { Int'l } \\
\text { action }\end{array}$ & $\begin{array}{l}\text { National } \\
\text { action }\end{array}$ & $\begin{array}{l}\text { Int'l } \\
\text { act }\end{array}$ & $\begin{array}{l}\text { National } \\
\text { act }\end{array}$ & & & & \\
\hline $\begin{array}{l}\text { African Court of } \\
\text { Human and } \\
\text { Peoples' Rights } \\
\text { (ACtHPR) }\end{array}$ & 2006 & No & Yes & Yes & Yes & No & No & No & No & Yes & Yes & Yes & Yes \\
\hline $\begin{array}{l}\text { Andean Tribunal } \\
\text { of Justice (ATJ) }\end{array}$ & 1984 & Yes & Yes & Yes & Yes & Yes & Yes & Yes & No & No & Yes & Yes & No \\
\hline $\begin{array}{l}\text { Benelux Court of } \\
\text { Justice (BCJ) }\end{array}$ & 1974 & No & Yes & No & No & No & Yes & No & No & Yes & Yes & Yes & No \\
\hline $\begin{array}{l}\text { Central American } \\
\text { Court of Justice } \\
(\mathrm{CACJ}) \\
\end{array}$ & 1992 & Yes & Yes & No & Yes & No & Yes & Yes & Yes & Yes & No & Yes & Yes \\
\hline $\begin{array}{l}\text { Caribbean Court } \\
\text { of Justice }(\mathrm{CCJ}) \dagger\end{array}$ & 2005 & Yes & Yes & Yes & Yes & Yes & No & Yes & Yes & Yes & Yes & Yes & No \\
\hline $\begin{array}{l}\text { Central African } \\
\text { Economic and } \\
\text { Monetary } \\
\text { Community } \\
\text { Court of Justice } \\
(\text { CEMAC CJ) } \\
\end{array}$ & 2000 & Yes & Yes & Yes & Yes & Yes & Yes & Yes & Yes & Yes & No & Yes & No \\
\hline $\begin{array}{l}\text { Court of Justice } \\
\text { of the European } \\
\text { Union (CJEU) }\end{array}$ & 1952 & Yes & Yes & Yes & Yes & Yes & Yes & Yes & No & Yes & Yes & Yes & No \\
\hline $\begin{array}{l}\text { Common Market } \\
\text { for Eastern and } \\
\text { Southern Africa } \\
\text { Court of Justice } \\
(\text { COMESA CJ) }\end{array}$ & 1998 & Yes & Yes & Yes & Yes & Yes & Yes & Yes & Yes & Yes & Yes & Yes & No \\
\hline $\begin{array}{l}\text { East African } \\
\text { Court of Justice } \\
(\text { EACJ) }\end{array}$ & 2001 & Yes & Yes & Yes & Yes & Yes & Yes & Yes & Yes & Yes & No & Yes & Yes \\
\hline
\end{tabular}




\begin{tabular}{|c|c|c|c|c|c|c|c|c|c|c|c|c|c|}
\hline $\begin{array}{l}\text { Economic Court } \\
\text { of the } \\
\text { Commonwealth } \\
\text { of Independent } \\
\text { States (ECCIS) }\end{array}$ & 1993 & No & No & No & Yes & No & No & No & No & Yes & Yes & Yes & No \\
\hline $\begin{array}{l}\text { Economic } \\
\text { Community of } \\
\text { West African } \\
\text { States Court of } \\
\text { Justice } \\
\text { (ECOWAS CJ) }\end{array}$ & 2002 & Yes & Yes & No & Yes & Yes & Yes & Yes & No & Yes & Yes & Yes & No \\
\hline $\begin{array}{l}\text { European Court } \\
\text { of Human Rights } \\
\text { (ECtHR) }\end{array}$ & 1959 & Yes & No & Yes & Yes & No & No & No & No & No & Yes & Yes & Yes \\
\hline $\begin{array}{l}\text { European Free } \\
\text { Trade Agreement } \\
\text { Court of Justice } \\
\text { (EFTA CJ) }\end{array}$ & 1994 & Yes & Yes & Yes & Yes & Yes & No & Yes & No & Yes & Yes & Yes & No \\
\hline $\begin{array}{l}\text { Inter-American } \\
\text { Court of Human } \\
\text { Rights (IACtHR) }\end{array}$ & 1979 & No & Yes & Yes & Yes & No & No & No & No & Yes & Yes & Yes & Yes \\
\hline $\begin{array}{l}\text { International } \\
\text { Criminal Court } \\
\text { (ICC) }\end{array}$ & 2002 & No & No & Yes & Yes & No & No & No & No & Yes & Yes & Yes & Yes \\
\hline $\begin{array}{l}\text { International } \\
\text { Court of Justice } \\
(\text { ICJ })^{*}\end{array}$ & 1947 & No & No & No & Yes & No & No & No & No & Yes & Yes & Yes & Yes \\
\hline $\begin{array}{l}\text { International } \\
\text { Criminal } \\
\text { Tribunal of } \\
\text { Rwanda (ICTR) }\end{array}$ & 1994 & No & No & Yes & Yes & No & No & No & No & Yes & No & Yes & Yes \\
\hline $\begin{array}{l}\text { International } \\
\text { Criminal } \\
\text { Tribunal of the } \\
\text { former } \\
\text { Yugoslavia } \\
\text { (ICTY) }\end{array}$ & 1993 & No & No & Yes & Yes & No & No & No & No & Yes & No & Yes & Yes \\
\hline
\end{tabular}




\begin{tabular}{|c|c|c|c|c|c|c|c|c|c|c|c|c|c|}
\hline $\begin{array}{l}\text { International } \\
\text { Tribunal for the } \\
\text { Law of the Sea } \\
\text { (ITLOS)** }\end{array}$ & 1996 & Yes & No & No & Yes & Yes & No & No & No & Yes & Yes & Yes & Yes \\
\hline \begin{tabular}{|l|} 
Mercosur \\
Permanent \\
Review Tribunal \\
(Mercosur PRT)
\end{tabular} & 2002 & No & Yes & No & No & No & No & No & No & No & Yes & Yes & No \\
\hline $\begin{array}{l}\text { Organization for } \\
\text { the } \\
\text { Harmonization of } \\
\text { Business Law in } \\
\text { Africa Common } \\
\text { Court of Justice } \\
\text { and Arbitration } \\
\text { (OHADA CCJA) }\end{array}$ & 1996 & Yes & Yes & Yes & Yes & No & No & No & No & Yes & Yes & Yes & No \\
\hline $\begin{array}{l}\text { Tribunal of the } \\
\text { Southern African } \\
\text { Development } \\
\text { Community } \\
\text { (SADC Tribunal) }\end{array}$ & $2005-2010$ & Yes & Yes & Yes & Yes & Yes & No & Yes & No & Yes & Yes & Yes & Yes \\
\hline $\begin{array}{l}\text { Western African } \\
\text { Economic and } \\
\text { Monetary Union } \\
\text { Court of Justice } \\
\text { (WAEMU CJ) }\end{array}$ & 1995 & Yes & Yes & Yes & Yes & Yes & No & Yes & No & Yes & No & Yes & No \\
\hline $\begin{array}{l}\text { World Trade } \\
\text { Organization } \\
\text { Appellate Body } \\
(\text { WTO AB)*** } \\
\end{array}$ & 1994 & No & No & Yes & No & No & No & No & No & No & No & No & Yes \\
\hline $\begin{array}{l}\text { Notes: } \\
* \text { Coding is based } \\
* * \text { Direct access is } \\
* * * \text { WTO AB in pr } \\
\text { the public. } \\
\dagger \text { CCJ is coded bas } \\
\text { Sources: For admir } \\
\text { International Law, }\end{array}$ & $\begin{array}{l}\text { on contentiou } \\
\text { limited to Se } \\
\text { ractice does } \mathrm{p} \\
\text { ed on origina } \\
\text { aistrative revi } \\
\text { ch. } 8 \text {. All oth }\end{array}$ & $\begin{array}{l}\text { is disp } \\
\text { a Bed } \\
\text { bublish } \\
\text { liew suris } \\
\text { iew }\end{array}$ & $\begin{array}{l}\text { mber } \\
\text { isions } \\
\text { on. } \\
\text { er, Th } \\
\text { code }\end{array}$ & $\begin{array}{l}\text { put } \\
\text { Ter } \\
\text { utho }\end{array}$ & of $I$ & ss is & vech & 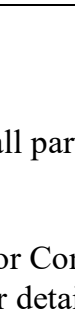 & ito & ute aq & tore & $\begin{array}{l}\text { dings } \\
\text { Terr }\end{array}$ & ade \\
\hline
\end{tabular}

